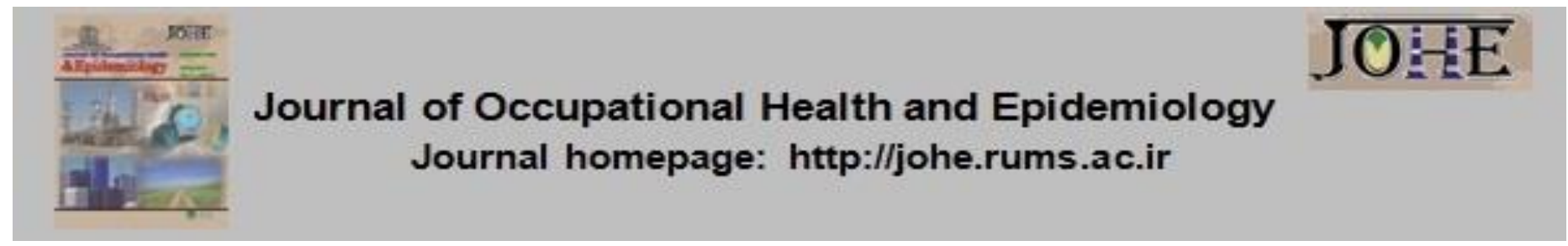

\title{
Explaining Occupational Themes of Marital Dissatisfaction in Dual-Career Couples: A Qualitative Study
}

\author{
Shahriar Dargahi ${ }^{1}$, Esmaeil Sadri Damirchi²*, Hossein Ghamari Givi ${ }^{3}$, Ali Rezaei Sharif², \\ Alimohammad Nazari ${ }^{4}$
}

1. PhD Student Counseling, University of Mohaghegh Ardabili, Ardabil, Iran.

2. Associate Prof., of Counseling, University of Mohaghegh Ardabili, Ardabil, Iran.

3. Professor of Counseling, University of Mohaghegh Ardabili, Ardabil, Iran.

4. Associate Prof., of Counseling, Shahroud University of Medical Sciences, Shahroud, Iran.

\section{Article Info}

\section{* Corresponding author: \\ Esmaeil Sadri Damirchi, E-mail: \\ e.sadri@uma.ac.ir}

\section{Article history \\ Received: May 2021 \\ Accepted: Jun 2021}

10.52547/johe.10.2.99

Print ISSN: 2251-8096 Online ISSN: 2252-0902

Peer review under
responsibility of Journal of
Occupational Health and
Epidemiology

Citation: Dargahi S, Sadri Damirchi E, Ghamari Givi H, Rezaei Sharif A, Nazari A. Explaining Occupational Themes of Marital Dissatisfaction in Dual-Career Couples: A Qualitative Study. JOHE 2021; 10(2):99-104.

\begin{abstract}
Background: Today, dual-career couples are becoming increasingly prevalent around the world. Due to the nature of the life of this group of people, the existence of multiple roles in the fields of work and the family, and the resulting marital problems, the present study aimed to explain occupational themes of marital dissatisfaction in dual-career couples.

Materials and Methods: The present study is a qualitative study that performs interpretive phenomenological analysis through semi-structured interviews with 13 dualcareer couples. Participants were purposefully selected from those who referred to counseling centers in Ardabil County, according to the inclusion criteria. Before the interviews, the participants, in addition to signing informed consent forms, responded to the sexual and marital satisfaction scale for initial evaluations and entry into the research. The thematic analysis method was used for data analysis.

Results: Based on participants' responses to the research questions, occupational themes of sexual and marital dissatisfaction with the dual career situation were classified into two main themes, including work-family conflicts and financial conflicts with five subthemes and 12 categories.

Conclusion: Based on the results, occupational themes of marital dissatisfaction in dualcareer couples have different dimensions. Due to the lack of qualitative research in this field, the results of the present study could be applied in the fields of psychopathology as well as in the prevention and treatment of marital and sexuality problems among dualcareer couples.
\end{abstract}

Keywords: Satisfaction, Couples, Qualitative

\section{Introduction}

The dual career phenomenon has become increasingly prevalent worldwide. This lifestyle often creates stress and strains at home and at work for couples with multiple demands, which can have negative consequences for organizations [1]. Although economic wellbeing is often provided among dual-career couples who have fewer material concerns, some of them may be faced with a variety of job-family conflicts. These conflicts could be due to some factors, such as job stress, heavy workload, role conflicts, childcare problems, adult care, and issues related to job-family balance and personal needs [2-4].

Among dual-career couples, a kind of role conflict exists in which role pressures resulting from working roles interfere with the role of individuals in the family [5]. Based on the study performed by 
Shimazu [6], more work and workaholism in women than in men can lead to job-family conflicts. Moreover, it has been reported that job-family conflicts may lead to a wide range of negative consequences, thereby decreasing marital satisfaction with and enjoyment of life moments [7, 8]. Couples' marital and sexual satisfaction is dependent on their perception of the sex life. Marital and sexual satisfaction is a variable that can be distinguished from sexual function. It is something beyond sexual pleasure, in the importance of which one can say that couples can have good sexual performance at any stage of the sexual response, yet they cannot experience marital and sexual satisfaction [9-11]. Marital and sexual satisfaction can be influenced by education, employment, job-family conflicts, marital problems, functional factors, and gender role conflicts [12, 13]. Past research shows that marital burnout, marital conflicts, marital problems, and psychological problems are more often observed among dual-career couples, and that there is a significant association between employment and marital problems among them [14, 15]. Results of studies having focused on positive aspects of dualcareer couples are indicative of lower sexual activity among women on a low income [16, 17].

The role of sexual and marital problems among couples in psychological, physical, and social dimensions, such as work environment is significant [18]. In addition, there are financial and role conflicts in some dual-career couples. Besides, marital issues affect these problems and role conflicts in the field of work and the family [13]. Accordingly, one could say that marital dissatisfaction is a variable that is directly and indirectly affected by many factors and also affects different aspects of life. Therefore, its reduction can play an important role in the vicious cycle of marital conflicts and other underlying problems. Given the increasing trend of dual-career couples in Iran and contradictions in quantitative studies, no qualitative study has yet been conducted in Iran to explain the underlying factors of the occupational index of marital dissatisfaction in dual-career couples. Therefore, it is necessary to pay attention to this group of people to prevent and fix problems existing among them. Against this background, this study aims to qualitatively identify and explain occupational themes of marital dissatisfaction among dual-career couples.

\section{Materials and Methods}

This qualitative research used the interpretive phenomenological analysis method. Interpretive phenomenology seeks to identify patterns in the data, which are placed in a theoretical framework [19]. Participants in the present study were dualcareer couples who were dissatisfied with sex and marriage. They were called and referred to counseling centers in Ardabil County from 2019 to 2020. The participants were selected and invited to participate in this study from the statistical population using the targeted selection method (8 couples), snowball sampling (5 couples), and by combining extreme or deviant case sampling.

Criteria for entering the study included perception of sexual and marital dissatisfaction by the volunteers participating in the study and having experienced at least 2 years of marriage life because Houston et al regards duration of marriage as one of the factors affecting marital satisfaction [20]. Another inclusion criterion was having at least one child because Tung et al found in a meta-analysis that the number of children was associated with marital satisfaction [21]. Other inclusion criteria were full-time employment of couples at public and private institutions, lack of drug or alcohol abuse, non-use of psychiatric drugs, lack of mental health problems, not having referred to courts for divorce during the research, lack of recognition of sexual dysfunction in either of the couples, and having no history of marital infidelity. The exclusion criteria were having psychological disorders and physical illnesses as well as lack of entry criteria. After semi-structured interviews with 11 couples, data were saturated. However, to increase diversity of concepts and to ensure data saturation, interviews were continued with 2 other couples. In the end, 13 couples were analyzed by way of thematic analysis.

The interviews that were conducted, both at couple and individual levels at the counseling center, lasted from 60 to 90 minutes. Next, the interviews were recorded and transcribed one by one. They were started with the questions "Are you generally satisfied with your marriage?" and "What is your experience of married life? "Next, they were guided on answers to questions, such as "What are your couple's barriers to the quality of married life?" Aliases (participants 1, 2, etc.) were used to preserve the subjects' details in the reports. When all interviews were conducted, the thematic analysis method, being common in phenomenology, was used to analyze the data obtained from the interviews [19]. To increase generalizability of the findings, it was attempted to differentiate the participants in terms of occupation, age, income, and education.

\section{Results}

A total of 13 couples participated in this study, 
whose demographic information is given in Table 1 (numbers 1 to 13 were assigned to couples in this section.). As Table 1 shows, research subjects were from different strata of the society with different levels of education. The duration of the research subjects' marriage varies from 5 to 20 years.

Table 1. Demographic characteristics of research subjects in terms of marital dissatisfaction

\begin{tabular}{|c|c|c|c|c|c|c|c|c|c|}
\hline \multirow{2}{*}{ Couple } & \multicolumn{2}{|c|}{ Marriage age } & \multirow{2}{*}{$\begin{array}{c}\text { Duration } \\
\text { of } \\
\text { marriage }\end{array}$} & \multicolumn{2}{|c|}{ Educational level } & \multicolumn{2}{|c|}{ Job } & \multirow{2}{*}{$\begin{array}{l}\text { Family } \\
\text { income }\end{array}$} & \multirow{2}{*}{$\begin{array}{l}\text { Number } \\
\text { of } \\
\text { children }\end{array}$} \\
\hline & Female & Male & & Female & Male & Female & Male & & \\
\hline 1 & 23 & 28 & 6 & $\begin{array}{l}\text { Associate } \\
\text { degree }\end{array}$ & $\begin{array}{c}\text { Bachelor's } \\
\text { degree }\end{array}$ & Employee & $\begin{array}{c}\text { Self- } \\
\text { employment }\end{array}$ & $\begin{array}{l}5 \text { Million } \\
\text { tomans }\end{array}$ & 1 \\
\hline 2 & 19 & 23 & 12 & $\begin{array}{c}\text { Bachelor's } \\
\text { degree }\end{array}$ & $\begin{array}{c}\text { Bachelor's } \\
\text { degree }\end{array}$ & Employee & Employee & $\begin{array}{c}6 \\
\text { Million } \\
\text { tomans }\end{array}$ & 2 \\
\hline 3 & 24 & 30 & 8 & $\begin{array}{l}\text { Master's } \\
\text { degree }\end{array}$ & $\begin{array}{l}\text { Associate } \\
\text { degree }\end{array}$ & Employee & $\begin{array}{c}\text { Self- } \\
\text { employment }\end{array}$ & $\begin{array}{l}5 \text { Million } \\
\text { tomans }\end{array}$ & 2 \\
\hline 4 & 26 & 30 & 9 & $\begin{array}{c}\text { Bachelor's } \\
\text { degree }\end{array}$ & $\begin{array}{c}\text { Bachelor's } \\
\text { degree }\end{array}$ & Employee & $\begin{array}{c}\text { Self- } \\
\text { employment }\end{array}$ & $\begin{array}{l}6 \text { Million } \\
\text { tomans }\end{array}$ & 2 \\
\hline 5 & 24 & 23 & 8 & $\begin{array}{l}\text { Master's } \\
\text { degree }\end{array}$ & $\begin{array}{l}\text { Master's } \\
\text { degree }\end{array}$ & Employee & Employee & $\begin{array}{l}5 \text { Million } \\
\text { tomans }\end{array}$ & 3 \\
\hline 6 & 21 & 25 & 19 & $\begin{array}{l}\text { Master's } \\
\text { degree }\end{array}$ & $\begin{array}{c}\text { Bachelor's } \\
\text { degree }\end{array}$ & Employee & Employee & $\begin{array}{c}4 \\
\text { Million } \\
\text { tomans }\end{array}$ & 2 \\
\hline 7 & 28 & 32 & 5 & $\begin{array}{l}\text { Bachelor's } \\
\text { degree }\end{array}$ & $\begin{array}{l}\text { Master's } \\
\text { degree }\end{array}$ & Employee & $\begin{array}{c}\text { Self- } \\
\text { employment }\end{array}$ & $\begin{array}{c}6 \\
\text { Million } \\
\text { tomans }\end{array}$ & 3 \\
\hline 8 & 25 & 29 & 16 & $\begin{array}{c}\text { Bachelor's } \\
\text { degree }\end{array}$ & $\mathrm{PhD}$ & Employee & Employee & $\begin{array}{c}8 \\
\text { Million } \\
\text { tomans }\end{array}$ & 1 \\
\hline 9 & 27 & 33 & 12 & $\begin{array}{l}\text { Master's } \\
\text { degree }\end{array}$ & $\begin{array}{l}\text { Master's } \\
\text { degree }\end{array}$ & Employee & Employee & $\begin{array}{c}5 \\
\text { Million } \\
\text { tomans }\end{array}$ & 2 \\
\hline 10 & 25 & 34 & 9 & $\begin{array}{c}\text { Bachelor's } \\
\text { degree }\end{array}$ & $\begin{array}{c}\text { Bachelor's } \\
\text { degree }\end{array}$ & Employee & Employee & $\begin{array}{c}4 \\
\text { Million } \\
\text { tomans }\end{array}$ & 1 \\
\hline 11 & 28 & 31 & 7 & $\begin{array}{c}\text { Bachelor's } \\
\text { degree }\end{array}$ & $\begin{array}{l}\text { Master's } \\
\text { degree }\end{array}$ & Employee & $\begin{array}{c}\text { Self- } \\
\text { employment }\end{array}$ & $\begin{array}{c}7 \\
\text { Million } \\
\text { tomans }\end{array}$ & 2 \\
\hline 12 & 34 & 30 & 8 & $\begin{array}{l}\text { Master's } \\
\text { degree }\end{array}$ & $\begin{array}{c}\text { Bachelor's } \\
\text { degree }\end{array}$ & Employee & Employee & $\begin{array}{c}6 \\
\text { Million } \\
\text { tomans }\end{array}$ & 1 \\
\hline 13 & 23 & 28 & 9 & $\begin{array}{l}\text { Master's } \\
\text { degree }\end{array}$ & $\begin{array}{c}\text { Bachelor's } \\
\text { degree }\end{array}$ & Employee & Employee & $\begin{array}{c}7 \\
\text { Million } \\
\text { tomans }\end{array}$ & 2 \\
\hline
\end{tabular}

In this study, two main occupational themes were obtained in terms of marital dissatisfaction among dual-career couples, which included "work-family conflicts" and "financial conflicts". Besides, 5 sub- themes and 14 categories were obtained. Table 2 shows a summary of qualitative findings of this research.

Table 2. Occupational themes of marital dissatisfaction among dual-career couples

\begin{tabular}{|c|c|c|}
\hline Main themes & Sub-themes & Categories \\
\hline \multirow[b]{2}{*}{$\begin{array}{l}\text { Work-family } \\
\text { conflicts }\end{array}$} & $\begin{array}{l}\text { Occupational-marital } \\
\text { conflicts }\end{array}$ & $\begin{array}{l}\text { "Not accepting and supporting one's spouse's employment", "Lack of } \\
\text { mutual understanding" and "lack of sufficient support from the spouse" }\end{array}$ \\
\hline & $\begin{array}{l}\text { Interference of work } \\
\text { role with the family } \\
\text { role }\end{array}$ & $\begin{array}{l}\text { "Pressure from interferences of roles related to work, spouse, and parental } \\
\text { role", "Pressure from other (non-job) and family roles" }\end{array}$ \\
\hline \multirow{3}{*}{$\begin{array}{l}\text { Financial } \\
\text { conflicts }\end{array}$} & Financial preference & "Priorities of financial issues", "Pure financial incentives" \\
\hline & $\begin{array}{l}\text { Financial humiliation } \\
\quad \text { and violence }\end{array}$ & $\begin{array}{l}\text { " Financial humiliation of the spouse", "Prohibition of the spouse in financial } \\
\text { decisions", "Dependence on and control over how one's spouse's income } \\
\text { is spent", "Perception of financial abuse" }\end{array}$ \\
\hline & $\begin{array}{l}\text { Improper financial } \\
\text { interactions }\end{array}$ & $\begin{array}{l}\text { "Financial secrecy and distrust", "Lack of financial fairness", "Lack of } \\
\text { proper financial rules and agreements", "Lack of financial commitment and } \\
\text { responsibility" }\end{array}$ \\
\hline
\end{tabular}


Work-family conflicts: This main theme has 4 categories and 2 sub-themes, including "interference of work roles with family roles" and "occupational-marital conflicts".

Interference of work roles with family roles: This sub-theme consists of two categories, including "pressure caused by interferences of work-related roles and from spouse and parental roles" as well as "pressure from surplus (non-job) and family roles".

The research subjects were very dissatisfied with the feeling of fatigue and a lot of pressure imposed on them in connection with the tasks assigned to them in the work environment. Besides, they were dissatisfied with the duties of the family environment, including those of the spouse, parents, etc. In addition to job duties, some nonjob affairs, such as buying food and non-food items for home, children's financial issues, banking affairs, and the like were done alone in addition to their job duties, having been regarded extra pressure of job and family roles.

Occupational-marital conflicts: This sub-theme is composed of 2 categories, including "nonacceptance and support of the employed spouse" and "lack of mutual understanding and sufficient support from the spouse".

The research subjects, especially women in this field, reported the most important cause of marital dissatisfaction and reduction in sexual desire for the spouse as a modern life with traditional patriarchy, i.e. a kind of interference of traditional thinking in modern life. According to them, in the married life of this group of couples, men would not make necessary changes to their own beliefs, norms, and values necessary for their lives.

Financial conflicts: This main theme has 12 categories and three sub-themes, including "financial preferences", "financial humiliation and violence", and "improper financial interactions".

Financial preferences: This subtheme consists of 2 categories, including "priorities of financial issues" and "mere financial incentives".

Accordingly, understanding most of dual-career couples dissatisfied with sex and marriage would be connected with their job and income. In general, their perception of money and job was interconnected.

Financial humiliation and violence: This subtheme consists of four categories, including "financial humiliation of the spouse", "prevention of the spouse from making financial decisions", "dependence and control over how the spouse's income is spent", and "perception of financial abuse".

Some problems in the families of dual-career couples affect their emotional life in an imperceptible and non-linear manner and are less known, which lead to financial humiliation of and violence against the working spouse. Financial humiliation reduces one's partner's authority over accessing financial resources and the way a family's financial income is spent while both working couples work equally hard to earn money.

Improper financial interactions: This subtheme consists of 4 categories, including "secrecy and financial distrust", "lack of financial justice and fairness", "lack of financial rules and agreements", and "lack of financial commitment and responsibility".

As both dual-career couples spend the money they earn in their shared life, they expect to experience almost equal powers in all matters and in the family. Therefore, if they do not appropriately consider financial relationships between themselves and their spouses as equal, they will lead to severe conflicts based on a common rule and agreement, such as the rule of the shared pocket.

\section{Discussion}

Analysis results of the concepts obtained in this study showed that one of the job themes of marital dissatisfaction in dual-career couples was workfamily conflicts among working couples, which included interference of the work role with the family role and occupational-marital conflicts. We will discuss this theme and its concepts.

When responsibilities, worries, and pressures shift from one field of work and the family to another, the balance of vision and responsibilities between dual-career couples is upset, thereby exposing them to marital and occupational burnout [22]. Work-family conflicts negatively and work-family enrichment positively affect marital and sexual satisfaction in dual-career couples [23]. Jurković showed that work-family conflicts would reduce sexual wellbeing and quality of marital relationships [24]. Similarly, Porshahbaz et al showed that sexual role conflicts in the fields of work and the family and failure to resolve them would lead to severe marital dissatisfaction [13].

Regarding lack of acceptance and support from the spouse, Hentschel et al concluded that inflexibility in traditional gender roles could be harmful for both women and men [25]. According to research, husbands with a more traditional view of gender roles experience more marital dissatisfaction [26].

In general, if spouses, especially husbands, do not make changes to their traditional sexual roles in their married life, that is, if they do not adapt to living conditions, they will most likely experience 
marital conflicts as well as marital and sexual problems.

Analysis results of the concepts obtained in this study show that the job themes of marital dissatisfaction in dual-career couples include financial conflicts caused by the income of the working couples. This would include the themes of financial preference, financial violence, and inappropriate financial relationships, which are reviewed in this section.

In line with the present study, Salimi et al, in their qualitative study, showed that financial preferences and financial incentives, and in contrast, lack of financial preferences were important components in conflicting and non-conflicting dual-career couples [27]. Besides, research conducted by Yurovich showed that dual-career couples seeking divorce had different conceptions of money, including an individual concept [28].

The results of the present research were in line with those of Salimi et al [27], which showed that financial humiliation of the spouse would be one of the important factors in marital conflicts between dual-career couples. According to the studies conducted by Vogler et al and Burgoyne et al, couples with individual ownership experienced more conflicts, yet those with joint ownership experienced less marital conflicts, being consistent with the present study [29, 30]. To explain this theme and its role in marital dissatisfaction, one could say that when the need for respect and values is not met in a person, they cannot be satisfied, thereby not enjoying sexual life and marriage.

To examine the third theme, i.e. inadequate financial relationships, the results of the study of Richlin and Hansen showed that perception of justice and equality in dual-career couples would be related to marital adjustment [31]. The research conducted by Zimmerman and Robert showed that financial management of the family would be one of the major factors determining dynamics and quality of marital relationships [32]. According to the findings of this part of the research, factors leading to the emergence of these categories include lack of self-sacrifice, lack of responsibility, lack of commitment, and in general, lack of marital identity in couples.

Some of the subjects' statements were about unfairness of their spouses' behavior and financial performance. According to the statement, "all costs are borne by me", couples' perception of stressful conditions and limitations would seriously damage the quality of their marital relationship, especially sex [32]. Accordingly, lack of financial management skills in dual-career couples would cause confusion in their financial relationships, thereby making them get engaged in chronic marital conflicts. Chronic conflicts play a negative role in couples' sexual life. This research was conducted on dual-career couples in Ardabil County. To generalize the results to other working couples and cultures, enough care must be taken.

\section{Conclusion}

In general, job and financial conflicts between dual-career couples manifest themselves in the form of psychological problems, disputes over nonfinancial issues, as well as emotional and sexual problems.

\section{Acknowledgement}

The authors would like to thank all couples who assisted us with this research.

Conflict of interest: None declared.

\section{References}

1. Elloy DF, Smith CR. Patterns of stress, work-family conflict, role conflict, role ambiguity and overload among dual-career and single-career couples: an Australian study. Cross Cultural Management: An International Journal 2003; 10(1):55-66.

2. Hammer LB, Neal MB, Newsom JT, Brockwood $\mathrm{KJ}$, Colton CL. A longitudinal study of the effects of dual-earner couples' utilization of family-friendly workplace supports on work and family outcomes. J Appl Psychol 2005; 90(4):799-810.

3. Dargahi S, Rezaiee Ahvanuiee M, Ghasemi Jobaneh $\mathrm{R}$, Khorasani $\mathrm{AH}$. The effect of relationship enhancement approach training on job stress and quality of marital relationship among municipality staffs. J Occu Health Epidemiol 2017; 6(4):199-206.

4. Mousavi SM, Samavatyan $H$, Nouri $A$. Effectiveness of work life quality improvement training and enrichment of marital life training on increasing the quality of work life and job satisfaction among of Dual-Career Couples. Biannual Journal of Applied Counseling 2019; 9(2):109-31.

5. Gurbuz S, Turunce O, Celik M. The impact of perceived organizational support on workfamily conflict: Does role overload have a mediating role? Economic and Industrial Democracy 2013; 34(1):145-60.

6. Shimazu A, Demerouti E, Bakker AB, Shimada K, Kawakami N. Workaholism and well-being among Japanese dual-earner couples: a spillover-crossover perspective. Soc Sci Med 2011; 73(3):399-409.

7. Camgoz SM. The Role of Savoring in WorkFamily Conflict. Social Behavior and 
Personality: an international journal 2014; 42(2):177-88.

8. Vil NM. African American Marital Satisfaction as a Function of Work-Family Balance and WorkFamily Conflict and Implications for Social Workers. J Hum Behav Soc Environ 2014; 24(2):208-16

9. Forbes MK, Eaton NR, Krueger RF. Sexual Quality of Life and Aging: A Prospective Study of a Nationally Representative Sample. J Sex Res 2017; 54(2):137-48.

10. Cybulski M, Cybulski L, Krajewska-Kulak E, Orzechowska M, Cwalina U, Jasinski M. Sexual Quality of Life, Sexual Knowledge, and Attitudes of Older Adults on the Example of Inhabitants Over 60s of Bialystok, Poland. Front Psychol 2018; 9:483.

11. Brotto L, Atallah S, Johnson-Agbakwu C, Rosenbaum T, Abdo C, Byers ES, et al. Psychological and Interpersonal Dimensions of Sexual Function and Dysfunction. J Sex Med 2016; 13(4):538-71.

12. Obradović J, Čudina- Obradović M. WorkRelated Stressors of Work-Family Conflict and Stress Crossover on Marriage Quality. Social Research: A Journal for General Social Issues 2009; 18(3(101)):437-60.

13. Pourshahbaz A, Eftekhar Ardebili M, Dolatshahi B, Ranjbar H, Taban M. Gender role conflict: Is it a predictor of marital dissatisfaction? A cross sectional study in Tehran. Med J Islam Repub Iran 2020; 34:84.

14. Stevens DP, Minnotte KL, Mannon SE, Kiger G. Examining the "Neglected Side of the WorkFamily Interface" Antecedents of Positive and Negative Family-to-Work Spillover. J Fam Issues 2007; 28(2):242-62.

15. Obradovic J, Cudina-Obradovic M. Work Stress and Marital Quality in Dual Earner Couples: A Test of Three Mediation Models. Social Research: A Journal for General Social Issues 2013; 22(4):673-91.

16. Perrone KM, Worthington EL Jr. Factors influencing ratings of marital quality by individuals within dual-career marriages: $A$ conceptual model. J Couns Psychol 2001; 48(1):3-9.

17. Sheikhan Z, Pazandeh F, Azar M, Ziaei T, Alavi Majd H. Survey on Sexual Satisfaction Situation and Some of Affecting Agents in Postmenopausal Women. Journal of Advances in Medical and Biomedical Research 2010; 18(71):81-9.

18. Lev-Ari S, Gepner Y, Goldbourt U. Dissatisfaction with Married Life in Men Is Related to Increased Stroke and All-Cause Mortality. J Clin Med 2021; 10(8):1729.

19. Abedi Ja'fari H, Taslimi MS, Feghi A, Sheykhzade M. Theme Analysis and Content Network: A Simple and Efficient Method for Explaing Patterns Embedded in Qualitative Data Municipalities. Strategic Management Thought 2011; 5(2):151-98.
20. Huston TL, McHale SM, Crouter AC. When the honeymoon's over: Changes in the marriage relationship over the first year. In: Gilmour R, Duck S, editors. The Emerging Field of Personal Relationships. 1st ed. Oxfordshire, England, United Kingdom: Routledge; 1986. P.109-32.

21. Twenge JM, Campbell WK, Foster CA. Parenthood and Marital Satisfaction: A Meta-Analytic Review. Journal of Marriage and Family 2003; 65(3):574-83.

22. Yusuf RM, Hasnidar H. Work-family conflict and career development on performance of married women employees: Case of Bank Employees, Indonesia. International Journal of Research in Business and Social Science 2010; 9(1):151-62.

23. Son BY, Kim SJ. The Effects of Dual-Earner Couple's Gender Role Attitude and Work-family Experience on Marrital Satisfaction. Journal of the Korea Academia-Industrial Cooperation Society 2020; 21(11):326-33.

24. Jurković L. The Role of Work-Family Conflict and Relationship Satisfaction in the Sexual Well-Being of Working Adults. Social Research: A Journal for General Social Issues 2020; 29(4):621-41.

25. Hentschel T, Heilman ME, Peus CV. The Multiple Dimensions of Gender Stereotypes: A Current Look at Men's and Women's Characterizations of Others and Themselves. Front Psychol 2019; 10:11.

26. Pourmohseni Kolouri F, Zohri N, Atadokht A, Mowlaie $M$. The role of dark personality dimensions, self-differentiation and gender roles in predicting marital burnout. Journal of Family Psychology 2020; 6(2):43-56.

27. Salimi Bajestani H, Rahimi R, Farahbakhsh K, Asgari M. Financial Conflicts and Compatibility in Dual-Career Couples: A Phenomenological Study. Social Welfare Quarterly 2020; 20(76):39-86.

28. Raz-Yurovich L. Economic Determinants of Divorce among Dual-Earner Couples: Jews in Israel. Eur J Popul 2012; 28(2):177-203.

29. Vogler C, Lyonette C, Wiggins RD. Money, Power and Spending Decisions in Intimate Relationships. Sociol Rev 2008; 56(1):117-43.

30. Burgoyne CB, Reibstein J, Edmunds A, Dolman V. Money management systems in early marriage: Factors influencing change and stability. J Econ Psychol 2007; 28(2):214-28.

31. Rachlin VC, Hansen JC. The Impact of Equity or Egalitarianism on Dual-Career Couples. Fam Ther 1985; 12(2):151.

32. Zimmerman K, Roberts $C$. The Influence of a Financial Management Course on Couples' Relationship Quality. Journal of Financial Counseling and Planning 2012; 23(2):46-54.

33. Ledermann $T$, Bodenmann $G$, Rudaz $M$, Bradbury TN. Stress, Communication, and Marital Quality in Couples. Fam Relat 2010; 59(2):195-206. 